\title{
INTERNET MEDIA IN MARKETING COMMUNICATION OF POLISH COMPANIES
}

The main objective of this article is to present the possibilities and scope of the use of new media for the necessities of marketing communications. The theoretical basis consists of scholarly literature relating to the described problem. In the empirical part the results of the author's own research are presented, on the topic of Internet media in marketing communication of Polish companies. The study was performed in two fields. The first relates to analysis of the content of websites, in terms of the use of the tools of the public relations. On this basis, a diagnosis was performed of the state of current usage of new media in public relations. In the second field, the research was performed in the form of a prognosis, relating to the growing trends of electronic media over the next few years based on interviews of experts. The last part of the research, showed that experts generally agree on the anticipated trends in the analyzed material. The most important of the likely changes in the next few years passed, among others, the multidimensional development of social media and mobile applications. Companies will seek to be involved in an increase of all channels of communication with customers, which include even videos and various graphics. In turn, the case of mobile applications must be developed in a variety of niche solutions (often abbreviated - cycle of life) and light versions of all major social networks - in this case mobile versions - can definitely become more popular.

Keywords: marketing communication, internet media, social media, public relations

\section{INTRODUCTION}

Modern marketing requires companies to communicate effectively with their current and potential clients. One of the ways of carrying out meaningful dialogue in business and its respective environment is the use of the Internet. New media, including the Internet, have stronger and stronger impact on socio-economic processes, resulting in a large change in the communication profile. Based on the increasing role of new media, a phenomenon called marketing 2.0 is developing, which refers to the transformation of marketing resulting from the impact of the internet on communication activities. Marketing 2.0 engages the consumers and evokes their feedback. Activation of customers is possible to a large extent by a well-executed action in the field of online PR (Internet public relations, web public relations, public relations network; e-PR). Thanks to this, the recipient

\footnotetext{
${ }^{1}$ Mariusz Woźniakowski dr, Katedra Marketingu, Wydział Zarządzania, Uniwersytet Łódzki, Łódź, ul. J. Matejki 22/26, m.wozniakowski@uni.lodz.pl, +48 426355051
} 
of the message is willing to interact, and even to initiate independent action. ${ }^{2}$ Currently, the formulation of marketing 3.0 appears more often, which refers to the so called new wave of technology, which allows connection and interactivity of individuals and groups. Clients can express themselves and collaborate with others without major restrictions, as a particular manifestation in the wave of the birth of social media. ${ }^{3}$ From this reason as well, it seems that no firm can lead effective communication with the environment any longer without the use of new media, which are used in the programs of internet public relations.

Instruments of internet public relations allow users to have constant communication and immediate response without restrictions in time and space. Due to the Internet, the audience is becoming increasingly widespread. Thanks to technology, the possibility exists to provide information to a selected group of customers, which has a special value in the design of communication. Thanks to interactivity, the Internet offers the possibility of continuous dialogue, which is a key feature of modern marketing communication. The Internet helps to reach different groups covered by public relations activities - clients and investors, the media, experts and opinion leaders, public institutions, as well as employees, agents and competitors, through individualized messages tailored to specific audiences. ${ }^{4}$

New media used in creating the image of the network is dynamically evolving, and therefore is an attractive and desirable area of promotional activities, arousing interest and attention of Internet users. Additionally, the Internet has a positive image in contemporary society, which means that companies are motivated to expose their online presence as well, in order to show that they are modern and open to new technologies and means of communication. ${ }^{5}$ The internet has made the PR field once again directed to the general public, after years of focus primarily on the media. ${ }^{6}$ Internet Public relations reinforces the overall effects of promotional campaigns on-line, creating a strong synergy. ${ }^{7}$

Evans noted that "new technologies are very important because it helps us to continually improve ourselves. This innovation of the Internet shapes and influences the models of many companies. Technological evolution can even completely change the business model". 8

${ }^{2}$ M. Cyran, Marketing 2.0. - zintegrowani z interaktywnymi, "Marketing w praktyce" 2008/10, p. 70-71.

M. Woźniakowski, Pinterest jako przejaw kultury obrazkowej w komunikacji marketingowej przedsiębiorstw, [in:] Marketing w obliczu nowych wyzwań rynkowych, ed. W. Grzegorczyk, Wydawnictwo Uniwersytetu Łódzkiego, Łódź 2013, p. 155-164.

${ }^{3} \mathrm{Ph}$. Kotler, H. Kartajaga, I. Setiawan, Marketing 3.0., MT Biznes sp. z o.o., Warszawa 2010, p. 18-19; B. Piekło, Zweryfikowany serwis internetowy, "Marketing w praktyce" 2011/2, p. 81-82.

${ }^{4}$ M. Kowalska, Zyskać przewagę. Zintegrowana komunikacja w nowoczesnym marketing. Między teoria a praktyka, Wydawnictwo Adam Marszałek, Toruń 2007, p. 111; M. Gajowniczek, Internet liderem!, "Marketing w praktyce" 2009/8, p. 32-34; T. Bonek, M. Smaga, Biznes w Internecie. Praktyczny poradnik o marketingu, sprzedaży, public relations on-line i promocji w mediach spolecznościowych, Wolters Kluwer Polska, Warszawa 2012, p. 45.

${ }^{5}$ W. Budzyński, Public relations, strategia i nowe techniki kreowania wizerunku, Poltext, Warszawa 2008, p. $115-116$.

${ }^{6}$ D.M. Scott, Nowe zasady marketingu i PR, Oficyna Wolters Kluwer Polska, Warszawa 2009, p. 49-50.

${ }^{7}$ G. Mazurek, Promocja w Internecie. Narzędzia. Zarzadzanie. Praktyka, Ośrodek Doradztwa i Doskonalenia Kadr, Gdańsk 2008, p. 95-96.

${ }^{8}$ L. "Li" Evans, Social media marketing. Odkryj potencjal Facebooka, Twittera i innych portali spolecznościowych, Helion, Gliwice 2011, p. 111 
As a fundamental tool of online public relations, a website should be considered. However, the modern, dynamic development of social marketing makes it increasingly the base of building the corporate identity in social media, which include ${ }^{9}$ :

- big portals - massive communities, eg. Facebook, Google+;

- business portals - communities of professionals eg. LinkedIn, GoldenLine;

- portals with videos and photos, eg. YouTube, Flickr, Instagram, Pinterest;

- blogs;

- microblogs, eg. Twitter;

- portals with articles, eg. iThink, Artelis;

- kickstarters, eg. Digg;

- individual social network.

The mentioned classification does not include all types of social media. Without a problem, you can make a further division because of their nature, functions, customers, etc.

This article focuses on the presentation of the author's own research results, on the online media in marketing communications of Polish companies carried out for the preparation of the doctoral dissertation. The study was conducted in two areas. The first relates to the analysis of the content of websites, in terms of using the tools of the internet public relations. On this basis, the diagnosis of the current state of network tools in the public relations sector through Polish companies was performed. The second area of research has been made in the form of predictions relating to the development of trends in electronic media over the next few years based on expert interviews conducted among representatives of business and education, dealing with this subject. ${ }^{10}$

\section{RESEARCH METHODOLOGY - ANALYSIS OF THE CONTENT OF WEB- SITES $^{11}$}

The first part of the research was based on analyses of website content for the use of instruments of online public relations. Firms that are in the category "Lista 500" are the largest Polish firms according to the newspaper "Rzeczpospolita" of April 2014 (16th edition). It was decided to use them, because it is a big business, thanks to extensive marketing departments (sometimes separate, isolated PR), and they have the resources for multiple activities in the field of marketing communication, including those conducted using electronic media. Finally, in many aspects of communication, big companies are pioneers and leaders in the use of new solutions and technologies.

The survey was conducted between June and July 2014 by two independent auditors (one of whom was the author of this paper) in order to eliminate errors that a single person could commit by analyzing the web pages.

The analysis was made in two areas:

\footnotetext{
${ }^{9}$ A. Mac, E-przyjaciele. Zobacz, co media spotecznościowe moga zrobić dla Twojej firmy, Helion, Gliwice 2011, p. 20-25; A. Podlaski, Marketing spolecznościowy. Tajniki skutecznej promocji w social media, Helion, Gliwice 2011, p. 36-79; A. Miotk, Skuteczne social media, Helion, Gliwice 2013, p. 16; C. Treadaway, M. Smith, Godzina dziennie z Facebook marketingiem, Helion, Gliwice 2013, p. 23-36.

${ }^{10} \mathrm{M}$. Woźniakowski, Internetowe public relations $w$ komunikacji marketingowej przedsiębiorstw, unpublished doctoral dissertation, University of Lodz, Łódź 2014.

${ }^{11}$ Based on: M. Woźniakowski, Internetowe narzędzia public relations w komunikacji marketingowej największych polskich przedsiębiorstw, "Przegląd organizacji" 2015/6, p. 19-23.
} 
1. Corporate websites and the use of the instruments of online Public relations, operating within its boundaries (directly related to the site);

2. Communication through the website with the use of the online public relations instruments, including social media.

Later in the article, for easier reading, the results of the data collected in both areas are presented together.

In the first area, it was checked if the company:

- has its own website in Polish. Websites in foreign languages were not analyzed further due to the assumption that, since these are the largest companies operating in Poland, they should communicate in Polish, with the environment in which they are operating;

- has on the webpage external links to other products or brands, specific to its ownership. These pages have not been analyzed;

- provides RSS feeds for the selected content from the page; also pressrooms

- is available to customers on the website in any form of interactivity or multimedia;

- communicate via the Web about the ongoing sponsorship activities, both off and online. In this section, it was taken into account both the typical sponsorship activities and CSR, since the latter (as well as sponsorship) affect the positive perception of the company by the environment, and often de facto take the form of sponsorship;

- has a pressroom. As pressroom tabs are not classified as "news" with only a specified list of events in the Company and / or its surroundings;

- makes available on the corporate website the possibility of subscribing to the company's newsletter.

In the second area it was checked whether the company, via its own website, communicates (it was not checked if the company in general has one, but whether the existence is made known on the company website) using social media to communicate with the environment. These media include:

- blogs. It was checked whether in the case of information if the blog exists and is carried out in the framework of the page, or is independent;

- microblogs - Twitter;

a) social networking sites (without examining the content if there is a link to the company's profile in the site): Facebook, YouTube, Google+, others.

The 500 analyzed companies were divided into 18 branches, whose activity is entered in the register of PKD (Polish Classification of Activities) as dominant (Table 1). Due to the recipients, pages were created in three categories (segments) of customers:

1. B2B - typically for corporate services;

2. B2C - for services dedicated to individual customers;

3. B2B/B2C - for parties of mixed character, dedicated to both the above two groups, such as commercial network service on the one hand, with information about current promotions for clients, and on the other hand information on how to become a supplier or franchisee network.

Also bringing attention to the issue of the level of use of communication tools depending on the form of ownership, they were distinguished into four kinds, and in the analysis of each, the company is assigned to the dominant form of ownership:

1. state ownership; 
2. communal ownership;

3. private ownership;

4. foreign ownership.

Table 1. Number of representatives of sectors at „Lista 500”

\begin{tabular}{|c|c|c|c|c|c|c|c|c|c|}
\hline \multirow{2}{*}{$\begin{array}{l}\text { No. } \\
1\end{array}$} & \multirow{2}{*}{\begin{tabular}{|l|} 
Sector \\
Mining
\end{tabular}} & \multicolumn{2}{|c|}{ B2B } & \multicolumn{2}{|c|}{ B2B/B2C } & \multicolumn{2}{|c|}{ B2C } & \multicolumn{2}{|c|}{ Total } \\
\hline & & 5 & $1,00 \%$ & 1 & $0,20 \%$ & 0 & $0,00 \%$ & 6 & $1,20 \%$ \\
\hline 2 & Media & 1 & $0,20 \%$ & 4 & $0,80 \%$ & 1 & $0,20 \%$ & 6 & $1,20 \%$ \\
\hline 3 & Production of fuels & 3 & $0,60 \%$ & 3 & $0,60 \%$ & 0 & $0,00 \%$ & 6 & $1,20 \%$ \\
\hline 4 & $\begin{array}{l}\text { Post and } \\
\text { telecommunication }\end{array}$ & 0 & $0,00 \%$ & 7 & $1,40 \%$ & 0 & $0,00 \%$ & 7 & $1,40 \%$ \\
\hline 5 & IT & 11 & $2,20 \%$ & 1 & $0,20 \%$ & 0 & $0,00 \%$ & 12 & $2,40 \%$ \\
\hline 6 & Energy production & 4 & $0,80 \%$ & 11 & $2,20 \%$ & 1 & $0,20 \%$ & 16 & $3,20 \%$ \\
\hline 7 & Services & 8 & $1,60 \%$ & 11 & $2,20 \%$ & 1 & $0,20 \%$ & 20 & $4,00 \%$ \\
\hline 8 & Transport & 12 & $2,40 \%$ & 10 & $2,00 \%$ & 0 & $0,00 \%$ & 22 & $4,40 \%$ \\
\hline 9 & Production of metals & 22 & $4,40 \%$ & 1 & $0,20 \%$ & 0 & $0,00 \%$ & 23 & $4,60 \%$ \\
\hline 10 & Others & 11 & $2,20 \%$ & 11 & $2,20 \%$ & 3 & $0,60 \%$ & 25 & $5,00 \%$ \\
\hline 11 & Architecture & 23 & $4,60 \%$ & 1 & $0,20 \%$ & 3 & $0,60 \%$ & 27 & $5,40 \%$ \\
\hline 12 & $\begin{array}{l}\text { Production of machines } \\
\text { and equipment }\end{array}$ & 17 & $3,40 \%$ & 10 & $2,00 \%$ & 0 & $0,00 \%$ & 27 & $5,40 \%$ \\
\hline 13 & $\begin{array}{l}\text { Production of cars, trail- } \\
\text { ers and ships }\end{array}$ & 27 & $5,40 \%$ & 6 & $1,20 \%$ & 0 & $0,00 \%$ & 33 & $6,60 \%$ \\
\hline 14 & Retail & 2 & $0,40 \%$ & 11 & $2,20 \%$ & 23 & $4,60 \%$ & 36 & $7,20 \%$ \\
\hline 15 & Production of food & 13 & $2,60 \%$ & 29 & $5,80 \%$ & 7 & $1,40 \%$ & 49 & $9,80 \%$ \\
\hline 16 & $\begin{array}{l}\text { Production of chemical } \\
\text { products }\end{array}$ & 31 & $6,20 \%$ & 18 & $3,60 \%$ & 3 & $0,60 \%$ & 52 & $10,40 \%$ \\
\hline 17 & Financial services & 3 & $0,60 \%$ & 46 & $9,20 \%$ & 3 & $0,60 \%$ & 52 & $10,40 \%$ \\
\hline 18 & Wholesale trade & 58 & $11,60 \%$ & 22 & $4,40 \%$ & 1 & $0,20 \%$ & 81 & $16,20 \%$ \\
\hline & Total & 251 & $50,20 \%$ & 203 & $40,60 \%$ & 46 & $9,20 \%$ & 500 & $100,00 \%$ \\
\hline
\end{tabular}

Source: own study

In comparison to the most numerous group of companies engaged in wholesale trade, which is 16.2 per cent of all the surveyed companies, the vast majority of the public representatives of the industry include the segment of B2B (58 companies), which represents more than 70 percent of the general branch. These customers are the result of the business - the majority of industrial representatives direct their offers to institutional clients. The 
second in terms of number is the financial services industry which has 52 representatives (10.4 per cent of the surveyed companies), of which the majority is communication addressed to customers within the categories B2B/B2C - nearly 90 percent of the companies from whole sector. This seems logical, since the vast majority of banks or insurance companies direct their services to both individual clients and institutional clients. Ex aequo from financial services in terms of the number of entities in the industry is the production of chemical products, but here we are dealing with a deeper division due to the customers. So, the dominating recipients of 31 firms is B2B (around 60 percent of the industry) as well as $18 \mathrm{~B} 2 \mathrm{~B} / \mathrm{B} 2 \mathrm{C}$ (nearly 35 percent). This is due to the fact that part of companies manufacture products for further processing, which are purchased by other production companies, and some direct their services to both institutional clients and individual clients (for example, pharmaceutical companies). At the other extreme are the industries that have 6 representatives, which gives 1.2 percent. of the total for each industry, and they are: mining (with the majority of customers in the B2B segment), the media (with 66 per cent. recipients in a group $\mathrm{B} 2 \mathrm{~B} / \mathrm{B} 2 \mathrm{C}$ - the content is presented. in eg. the case of television stations for both the audience and potential advertisers) and the production of fuels (where all users belong to a group or B2B or B2B/B2C). A detailed list of sectors (as well as the number of representatives of each) in relation to the categories of customers is presented in Table 1

\section{THE USE OF ONLINE MEDIA BY POLISH COMPANIES}

The conducted analysis showed that all classified networks of public relations tools are used by companies from the list. All companies have websites with a domain name consisting mostly of the company name and .pl or .com.pl. However, not all entities have a website written in Polish. 95 percent of the surveyed companies have a page in Polish, 5 percent only have a page in a foreign language (usually by typing in the browser address from the Polish domain, followed automatically by being directed to the corporate global website operating under the .com domain - this situation is related only to foreign companies), another 5 percent have a page in both Polish (the most common is the incomplete version) and a foreign language.

In the case of the second tool - external links to a selected product/brand, 190 companies have them, representing 38 percent of the total. External links are the most common in the structure of the site's multibrand, where in the "Our Products" section, the description of the individual products and brands is shown.

Another tool - RSS is used by 85 companies, which represents 17 percent of the total. RSS feeds mostly function within the pressroom and relate to current information about the company.

Forms of interactive/multimedia, that are on the menu page, are referred to in different ways. They appear, among others, to determine: multimedia, photo bank, downloads, library, gifts and gadgets. With this type of support in the promotion, it was decided to use 239 companies (nearly 48 percent of the total sample). Usually, in this section there are photos and videos. Although there are exceptions, such as wallpapers and / or screensavers products or company logo in the background which are positioned for fans. An interesting form of interaction, gadgets for specific customers, a useful example, may be included on the part of Exide Technologies, the owner of the brand "Centra". So on the centra.com.pl page, in the main menu tab is "Adjust the battery". By clicking on it, we are 
redirected to dobierzakumulator.pl where we can choose the most suitable battery for our car, choosing the make, model, type of fuel, type and date of production of the car. Without a doubt, this interactive gadget is useful for many drivers who have doubts about how to choose the battery for their car.

Figure 1. The use of Internet public relations tools by companies listed at „Lista 500”

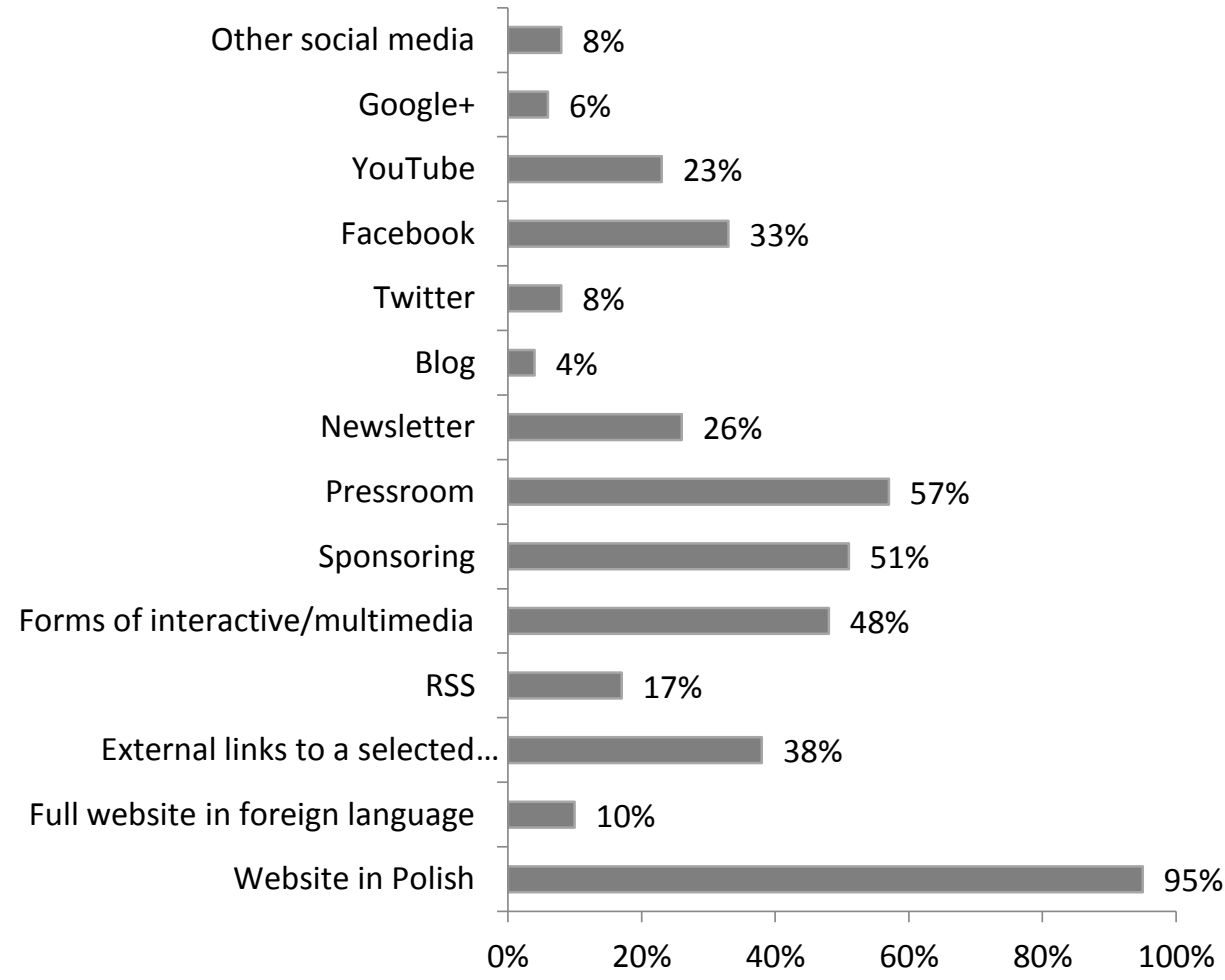

Source: own study

The next issue examined was communication, by means of a website, of the ongoing sponsorship activities. In this case, it was found that more than half of the companies (254 - 50.8 percent of the total sample) communicate on the company website that carry out activities in this field. However, for most of the companies, sponsoring is associated with corporate social responsibility (which the author of the paper agrees with, considering the effects, csr is building a positive image of the company and most often happens through support - in various forms - of a non-profit organization) - exactly 187 (from 254), and thus by nearly 74 percent of sponsorship communicating entities. It should be noted that the tabs on the sides bear, most often, the following names: "CSR", "social commitment", "we support", "social activities" as well as "sponsorship". Sometimes, in the area of CSR, appeared sports sponsorship, which shows how this concept is not explicitly defined. In regards to sponsorship, in its pure form, communicate only 21 of the companies while at 
the same time on sponsorship and CSR - 46. It should be noted that it is probable that not all companies that operate sponsoring communicate it via the Web.

In turn, pressrooms are used by 287 companies, which gives 57.4 percent of the total surveyed entities. In this case, too, it can happen, as with social media sponsorship, that the company has a virtual press office, but it does not inform about it on the Web.

In the case of the newsletter, it is available for 132 companies, which gives 26.4 percent of all surveyed companies. Generally, it is a tab on the home page with a request to enter an email address or the name displayed in the registration form, on which beyond the email address, you must enter your name (sometimes also the place of residence, or it should be noted which categories of information you are interested in).

\section{SOCIAL MEDIA IN MARKETING COMMUNICATION OF POLISH COM- PANIES}

The most popular social media among companies is Facebook. A link to your profile (mostly classic plugin on the main page, rarely in the form of dynamic - retractable, sometimes links to social media occurred in a separate tab in the menu, also as a subcategory in the pressroom) exists in 164 companies, representing 32.8 percent of the total. While not classified, no profiles in a language other than Polish exist. The second most popular was a YouTube connection on 112 pages (22.4 percent of all respondents), followed by Twitter - 41 (8.2 percent.), Often due to their nature, it was placed in the pressroom. Next was Google+ - 27 (5.4 percent of the total). Proving to be the least popular are blogs, which exist in only 23 companies (4.6 percent of respondents). However, the existing blogs can be considered a very interesting substance; carefully prepared and constantly guided in an attractive form.

Of all the surveyed companies - 42 (8.4 percent) also had links to other than those listed social networking sites, of which 32 connected from one other service, 7 from two, and 3 from up to three. The most common sites popping up here were networks of professionals associated with building a professional position - GoldenLine and LinkedIn. In two cases, it also appeared in the Polish service NK.pl. In three cases, there were rows of common services in Poland: Dailymotion and Slideshare. A detailed list of the other social networking sites are included in Table 2.

Table 2. The use of less popular social networking sites by companies listed at „Lista 500”

\begin{tabular}{|l|l|c|c|}
\hline No. & $\begin{array}{c}\text { The name of a social } \\
\text { networking site }\end{array}$ & $\begin{array}{c}\text { The number of companies using the } \\
\text { social networking site }\end{array}$ \\
\hline 1 & LinkedIn & 21 & $4,2 \%$ \\
\hline 2 & Pinterest & 12 & $2,4 \%$ \\
\hline 3 & GoldenLine & 11 & $2,2 \%$ \\
\hline 4 & Instagram & 6 & $1,2 \%$ \\
\hline 5 & Flickr & 4 & $0,8 \%$ \\
\hline 6 & NK.pl & 2 & $0,4 \%$ \\
\hline 7 & Slideshare & 2 & $0,4 \%$ \\
\hline 8 & Dailymotion & 1 & $0,2 \%$ \\
\hline
\end{tabular}

Source: own study 
Figure 2. The use of Internet public relations tools by companies listed at „Lista 500” divided into segments of customers (overall structure $\mathrm{B} 2 \mathrm{~B}+\mathrm{B} 2 \mathrm{~b} / \mathrm{B} 2 \mathrm{C}+\mathrm{B} 2 \mathrm{C}=100 \%$ )

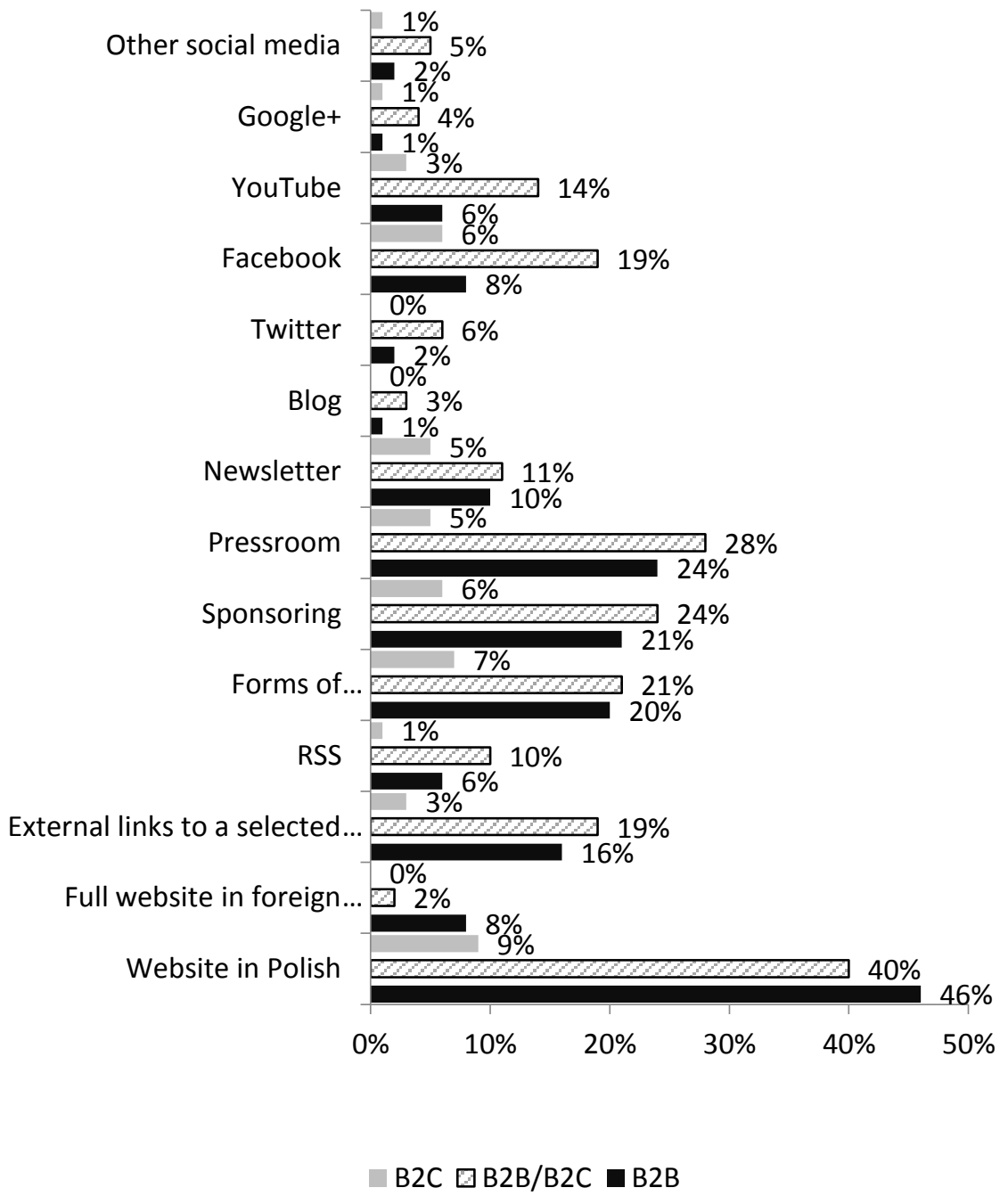

Source: own study

Looking through the prism of the general structure of customers of the websites - due to the number of individual customers (50.2 percent $\mathrm{B} 2 \mathrm{~B}$ percent of the surveyed companies, B2B/B2C 40.6 percent., B2C 9.2 percent. - Figure 2), the use of the various network tools of public relations is as follows: most pages in Polish (46 percent.) are directed to $\mathrm{B} 2 \mathrm{~B}$ recipients, 5 percent of companies do not have pages in this language - then we can obtain a global corporate website for the same customers. Despite the largest number being $\mathrm{B} 2 \mathrm{~B}$ recipients, other tools are targeted most often for mixed recipients B2B/B2C and they are: pressroom ( 28 percent.), sponsorships ( 24 percent.), forms of interactive / 
multimedia (21 percent.), Facebook (19 per cent. ), external links to the website product / brand (19.proc.), YouTube (14 percent.), newsletters (11 percent.), RSS (10 percent.), Twitter (6 per cent.), other social networking sites ( 5 percent .), Google (4 per cent.), and blogs ( 3 per cent.). Due to the small number of customers in only B2C (9.2 percent), none of these tools were not dominant among this group.

The situation is different if each of the audiences are treated as a single entity (100 percent.). The distribution of the use of instruments of Internet public relations in many places looks quite different (Figure 4.3). More than 90 percent of companies have a webpage in the Polish language in order to communicate their activities to all audiences, with the lowest percentage among companies whose recipients are from $\mathrm{B} 2 \mathrm{~B}$; here is the same as the highest percentage of foreign language sites (16 percent.). With the next two tools - forms of interactive/multimedia and RSS, it is clear that they are most often used by companies with customers of mixed B2B/B2C, it is respectively 47 and 25 per cent., And in this case, customers only from B2B or B2C segments are $15(+/-2)$ percentage points lower in each case. In turn, forms of interactive / multimedia are dominated by entities that operate B2C customers (76 percent.). In the case of the other customers, tools that companies use less often, although the percentages are still big - it is 52 percent for $\mathrm{B} 2 \mathrm{~B} / \mathrm{B} 2 \mathrm{C}$ and 40 percent for B2B. In the case of sponsorship, disparities are less visible in communicating within this form of activity, if customers are representatives of $\mathrm{B} 2 \mathrm{C}$ and B2B/B2C (respectively 65 and 59 percent), slightly less for B2B recipients - 42 percent. Pressrooms also proved to be a commonly used tool for public relations networks, regardless of the segment of the customers, although the maximum difference between using a pressroom, a group of customers is 21 percentage points. The most numerous, a virtual press office, is used by the company for customers B2B/B2C, as well as B2C and B2B and is respectively 69,54 and 48 percent. In the case of a newsletter, differences in the use according to the existing customers are large. Customers of $\mathrm{B} 2 \mathrm{C}$ have 54 percent of companies, in the other two groups, ie. for B2B/B2C and B2B this figure stands at 27 and 20 percent.

The degree of use of social media, depending on the target audience is definitely more diverse than it was in the case of tools directly relating to the company's Web site. It is not surprising that the most popular social networking site is Facebook. A link to your profile on their site exists in 65 percent of entities that direct their message to the $\mathrm{B} 2 \mathrm{C}$ segment. For $\mathrm{B} 2 \mathrm{~B} / \mathrm{B} 2 \mathrm{C}$ this amount is at the level of 47 percent, and for only 16 percent of $\mathrm{B} 2 \mathrm{~B}$, which in this case should not be surprising, because it is a site dedicated to mass communication, rather than building the business to business relationships. The second most popular communication with the public is YouTube, a video-based media. It is used by over 30 percent of companies that have their customers in segments $\mathrm{B} 2 \mathrm{~B} / \mathrm{B} 2 \mathrm{C}$ and $\mathrm{B} 2 \mathrm{C}$ and by 12 percent of entities operating within the B2B segment. A similar structure is used in the case of the next service - Google+, with the difference that the volumes are considerably smaller, and amount to 11,10 and 2 percent respectively, for B2C, B2B/B2C and B2B. For two consecutive social media - Twitter and blogs, the utilization rate of communication with customers from the B2C segment is zero. For groups B2B/B2C Twitter is used by 15 percent of businesses, and about 7 percent communicate with blogs (for B2B this amount is about 4 and 2 percent.). About the last category - other social networking sites used for communication with stakeholders via corporate websites, is 12 percent of companies for customers B2B/B2C, 11 percent. for B2C and only 4 percent for $\mathrm{B} 2 \mathrm{~B}$. Although in the latter case, the percentage could be higher if the company's frequent 
use of portals of professionals, and the fact that informed on the Website (there are many company profiles on sites including LinkedIn and GoldenLine, of which entrepreneurs do not mention on their website) .

Figure 3. The use of Internet public relations tools by companies listed at „Lista 500” divided into segments of customers (one segment $=100 \%)$

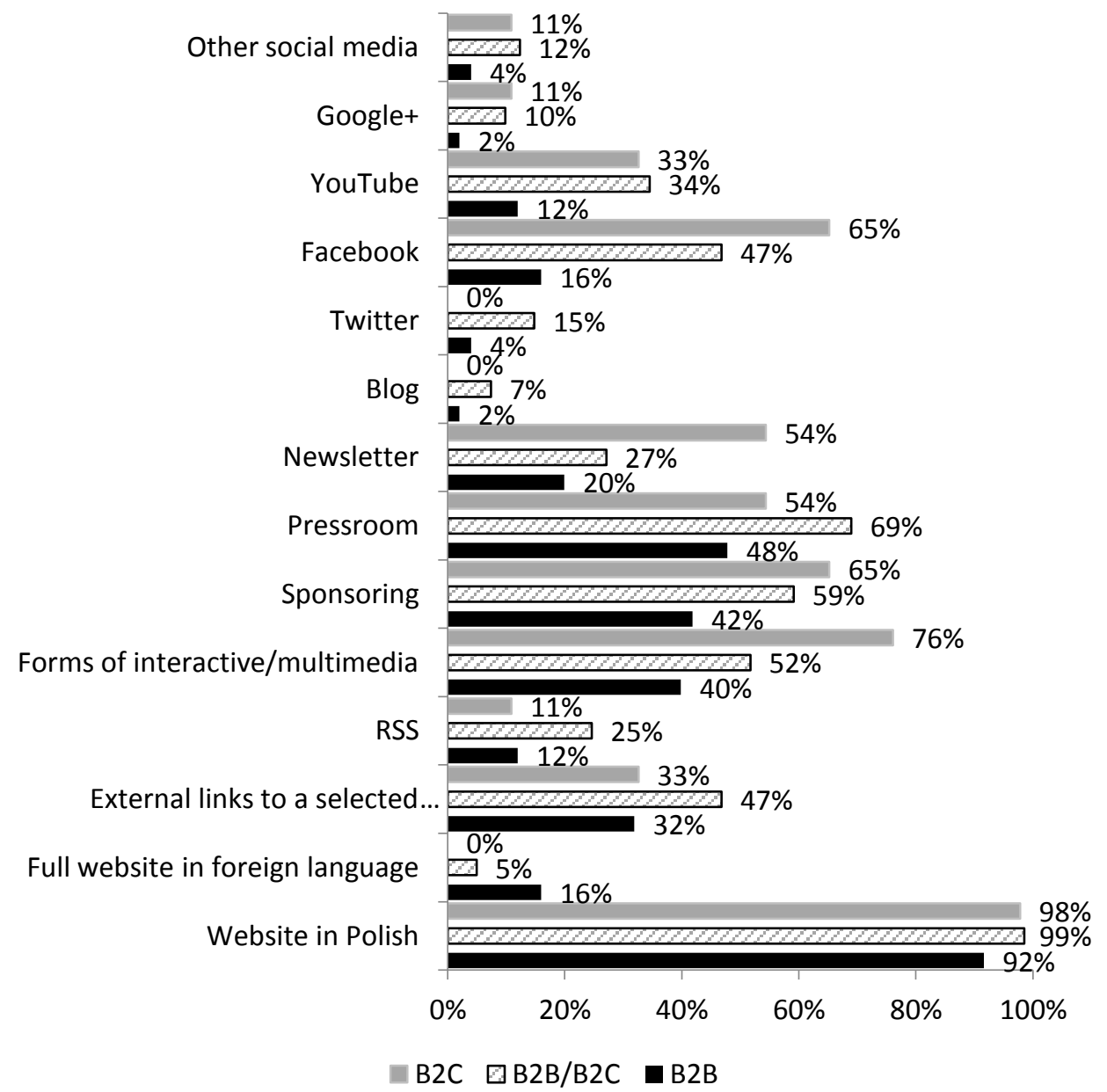

Source: own study

Information about the used social media, via website, most commonly are communicated by state-owned companies and foreign (Figure 4). Due to the large disparities in the various forms of property (34 state enterprises, 6 municipal, private 202, 258 overseas), the results of dealing in any form as a unity (100 percent.). Facebook is the most popular. 37 percent of foreign companies inform about their profile on the site, nearly 30 percent for public and private, and 17 percent for municipal. 17 percent of municipal communicate via Twitter, 14 percent of state and about 7 percent of private and foreign. Municipal 
enterprises do not communicate any more with the use of social media, hence will be omitted in the following description. Foreign entities are much more pro-social (in the sense of carrying out the activity in social media), but the analysis did not take into account the profiles provided in foreign languages. Often, it happened that a foreign company on the website written in Polish had installed numerous social plugins. Only when you click and redirect to the profile of a particular site it turned out that it is conducted in a language other than Polish. In this case, the assumption of the study is that the activity of the network in terms of of public relations was not classified.

Figure 4. The use of social media for each form of ownership

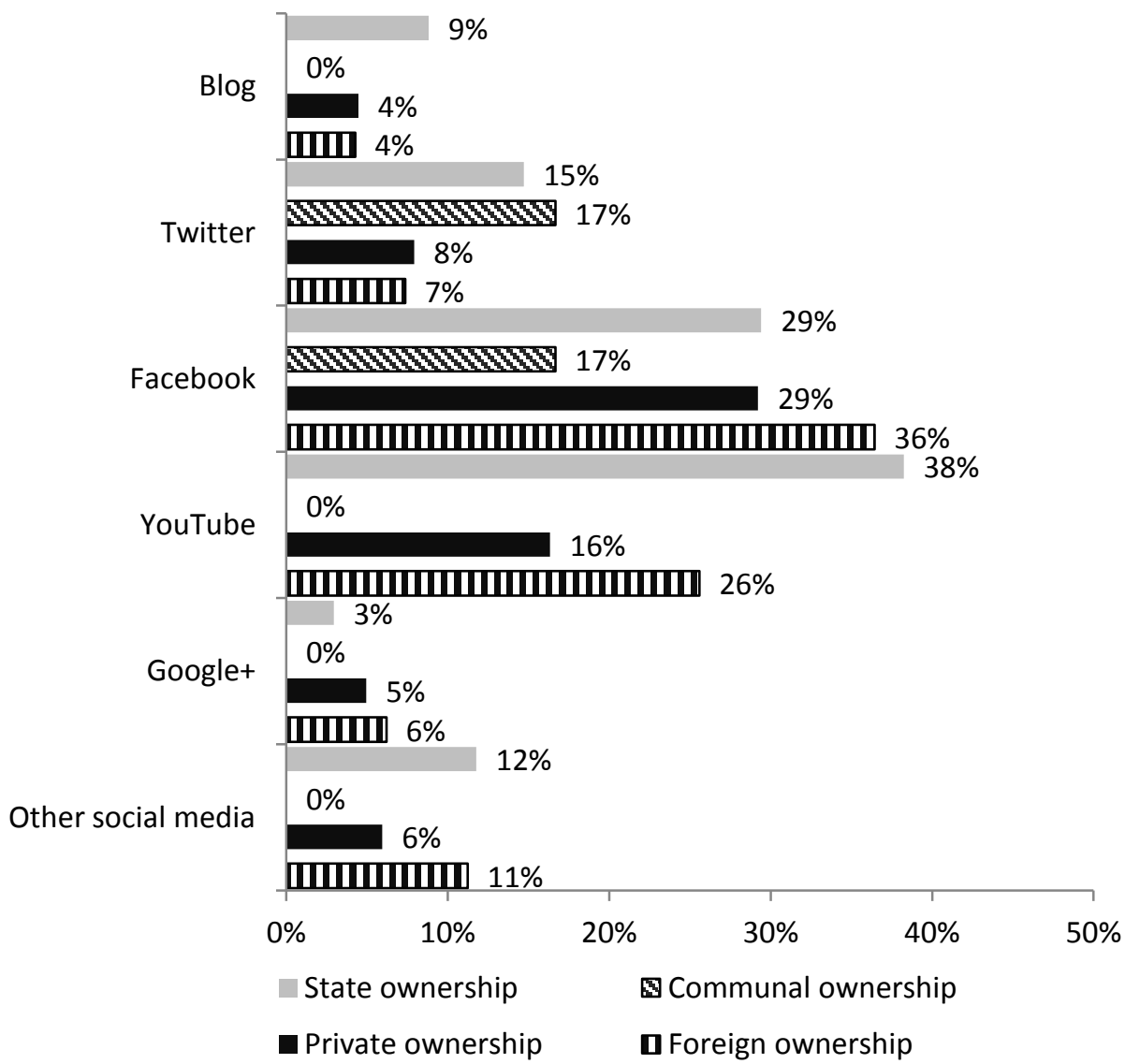

Source: own study

\section{DEVELOPMENT TRENDS OF ELECTRONIC MEDIA IN THE LIGHT OF EXPERTS}

The second part of the research consists of performing individual interviews about marketing communications, with special emphasis on public relations and network devel- 
opment trends in this area. The research was based on the earlier list of questions sent to respondents. This form of data collection was used, mainly to allow respondents to provide full and free statements but not limiting a cafeteria selection of responses and allowing respondents an opportunity to explain the essence of the questions, tasks and supplementary questions. The survey was conducted among:

1. five representatives of the companies (department workers responsible for activities such as public relations) conducting intensive activities in the field of Internet PR;

2. five representatives of public relations agencies affiliated to the Polish Association of Public Relations (PSPR);

3. five representatives of education - academics marketing departments of public universities (or other units of academics) dealing with issues of public relations.

According to experts, contemporary e-PR tools are required for each type of business activity due to the fact that the Internet has become the basic medium of searching for information about products, services, as well as bidders. The location of these tools, in order of importance in marketing communications, will certainly depend on the industry and target markets. For example, if a company offers products exclusively through marketing communication, it can be carried out solely on the basis of Internet public relations tools. In contrast, a company operating in a market dominated by the traditional distribution model will need offline tools, including the network due to the changing trends in communication.

To put the matter differently, destination network tools deal with public relations and marketing of communication departments, PR, HR or even IR. The role is to provide a coherent picture of the company (including the brand or brands) and its personal characteristics in the broad sense of its environment.

Experts suggest different trends in marketing communications over the next few years, but most of them are connected with the development of electronic media. Below are the quintessence of the experts' opinions on this field.

- One expert said that the answer to the question "can be closed in two words - speed and personalization," which means that customers expect instant service and what goes with it - intelligible communication. Any non-personalized, mass forms of communication will lose its significance. Therefore, companies are carrying out activities leading to better profiling offers for customers, which has resulted in a real usability for the customer.

- The growing importance of social marketing data. Thanks to automated tools for market research, it will be possible to choose a particular pattern of consumption, simultaneously increasing a meaning of tools for monitoring social media. After identification of the behavior of the company, we will be able to communicate directly with the client through the offers and promotions in social channels. Such large data analysis will allow the company / brand to watch, learn and adapt to the preferences of customers in all available social media.

- Content marketing will be the most significant in all social media platforms. Its growing popularity will make published content easily and widely available. High quality content will be the key to success in the process of communication with customers. More and more brands will create copyright content, dedicated to individual channels - articles, newsletters, videos and blogs that can be integrated with social networking. Greater responsibility will be resting on the PR departments due 
to the need for tracking the effects of actions taken - as created content is available in social media and what is its impact on sales and return on investment.

- A further increase in spending on public relations networks with particular emphasis on social media (including cost for paid promotional formats). The aim of the companies will be continuously increasing engagement across all channels of communication with customers. Consequently, this will mean an increase in spending on promoted formats, which also will increase the range and will be precisely tailored to the target group that the firm wants to acquire.

- Will increase the popularity of videos. The company/brand will be increasingly trying to create movies that will be viral or will strengthen the image. On this wave, YouTube will definitely grow in strength.

- We will have to deal with the development of mobile applications, and therefore their wide use by the environment, which will bring about the need for widespread use of these applications by companies to communicate with the environment.

- Increased emphasis on security and data protection, not only personal, but also those relating to the operation of companies in the cloud.

Experts agreed that the development of new mobile technology solutions supports the creation of a corporate image as modern, dynamic and open to the world; while providing high-quality service. Thus, mobile technologies allow for building brand personality, you can give it life in the world of micro-communications. In accordance with the above trends, technological developments and the need for effective time management are causing smartphones to take over as the primary tools to search for information about companies / brands, and increasingly through the mobile channel, the process itself runs sales and customer service. It must be remembered that not all mobile technologies will be for everyone - it depends on the industry and the market. As one of the most important trends in this area has been identified, the need to create sites in technology and RWD - Responsive Web Design.

\section{CONCLUSIONS}

The above analysis of Internet public relations tools relating directly to the web site and the extent of their use by Polish companies revealed that 95 percent of them have a corporate website in Polish. Others have a corporate website - global - in English, which, from the point of view of building the image on the Polish market may be perceived negatively. Even if there is no need to create complex pages, to show the connection with the place in which it operates you can even create a business card page. Other tools in this area are also quite actively used by businesses. More than half have their own pressroom and the same communicate via its own website about the ongoing sponsorship activities, while less than 50 percent of companies offer its customers the framework of various types of web pages in interactive forms and / or multimedia. More than a quarter of companies make a newsletter available on their websites.

Further analysis related to communication shows that Polish entrepreneurs use social media through their own sites, showing that the most popular social networking site is Facebook (more than 30 percent of companies have a plug-in for their own profile on this website). The later places were taken by YouTube (more than 20 percent.) and Google+ (more than 5 percent.). Less than 10 percent of companies also benefit from other services (usually appearing LinkedIn, Goldenline, Pinterest, and Instagram). 8 percent of entities 
communicate with the environment via Twitter. The least popular social media proved to blogs; only 5 percent of companies use them. In comparison with the first group of network tools of public relations, relating directly to the website, the percentage of companies using social media is small. This state of affairs, no doubt, is influenced by the work of many foreign companies, and so they have the plug-in on their sites to social networking sites, but all profiles are mostly conducted in English (they were not classified in the statement). In that case, there is little desire on the part of companies to translate messages and create, simply copies of their corporate profiles in Polish. The benefit would be mutual: the company is gaining a communication channel with the Polish audience, you know about the company, and additionally can interact (which is also beneficial to the other side).

Finally, the last part of this study showed that there are significant differences in the level of use of the network public relations tools depending on the industry and the market in which the company operates. By making some generalizations, it can be concluded that companies from which its activities are focused on the B2B audience in a much lesser extent, use the tools of e-PR in the communication process with the environment, than industries that, to a large extent, operate on the basis of b2c customers. Of course, there are some deviations from the general condition, as in the IT industry. But in this case, high activity in the field of public relations networks should be seen in the profile of these companies. This fact shows that Polish companies still have much to do in terms of communication with the use of social media. Looking at global trends, it is a mistake to leave social media only for $\mathrm{B} 2 \mathrm{C}$ communication. For most sites there is a huge potential for communication in the $\mathrm{B} 2 \mathrm{~B}$ market.

The second part of the empirical research, based on the opinions of experts in the field of public relations, has shown that it is possible to outline some common trends for marketing communications. The most important of the likely changes in the next few years, experts have concluded, among others, is multidimensional development of social media and mobile applications. In the case of the former, including the growing importance of data obtained from this source, which is expected to lead to building more personalized messages, companies will seek to be involved in an increase in all channels of communication with customers, which include even videos and various graphics (based the social media boom in the picture as YouTube, Pinterest and Instagram). In turn, the case of mobile applications must be developed in a variety of niche solutions, offering customized solutions in order to build commitment and light versions of all the major social networks - in this case, the mobile versions will become definitely more popular than their full counterparts.

\section{SUMMARY}

Interpersonal communication is constantly evolving, the same happens with communication on the field of enterprises (organization) - the client (or any other group of stakeholders). Various kinds of innovations introduced in this area can temporarily improve the process of communication or even revolutionize it, as was the case with the Internet.

Therefore, it would seem that the Internet market, and therefore marketing activities conducted within it, including the network of public relations have reached a certain maturity and stability in their development. The adoption of such an assumption would be too simplistic, because in parallel to the development of a network of mainstream, the 
development of alternative trends and business models is supported by implementing innovative tools. The past has shown that it can happen extremely fast (for example, the phenomenon of social media).

In subsequent years, certainly in the way we communicate, both for consumers and businesses, will be affected by the trend called "internet of things." In the coming years, people will surround themselves with billions of devices connected to the network. Already we have seen the impact of mobile devices on communication, both purely interpersonal and marketing. In this case, the technology begins to permeate everything that surrounds us, from cars, to RTV and household appliances, and our clothes. In such a world, public relations will permanently be associated with technology, a new media of communication. Certainly, you will need to redefine the PR network as a result of these changes. You will probably need to look again at the public relations as a whole, without division between online and off, since these limits will completely disappear.

As a result of the analysis of Internet public relations tools relating directly to the web site and the extent of their use by Polish companies, we found that 95 percent of them have a corporate website in Polish (the others are corporate websites - global - in English), more than half have their own pressroom and the same communicate via its own website about the ongoing sponsorship activities, while nearly 50 percent of companies offer its customers, in the framework of various types of web pages, interactive forms and/or multimedia. More than a quarter of companies make available on their websites a newsletter. Less frequent use of this tool, compared with the aforementioned, according to the specific characteristics - not in every industry and for each market will fulfill its role. Therefore, despite lower percentage of the latter, one can firmly say that Polish companies are willing to use network PR tools relating to their websites.

In the course of further analysis related to communication by Polish entrepreneurs of social media used through their own sites, we found that the most popular social networking site is Facebook (more than 30 percent. of companies a have plug-in for their own profile on this website), followed by YouTube (more than 20 percent) and Google+ (more than 5 percent.). Less than 10 percent of companies also benefit from other services (usually appearing LinkedIn, Goldenline, Pinterest, and Instagram). 8 percent of entities communicate with the environment via Twitter - a microblog platform. The least popular social media proved to be blogs, which are used by less than 5 percent of companies. In comparison to the first group of network tools of public relations, relating directly to the website, the percentage of companies using social media is small.

Another part of the empirical research shows that there are significant differences in the level of use of the network of public relations tools depending on the industry and the market in which the company operates. By making some generalizations, it can be concluded that companies from which its activities are focused on the B2B audience (for example, wholesale, automotive, trailers and ships, construction, metal production, mining) in a much lesser extent, use the tools of e-PR in the communication process with its environment, than industries that operate largely based on B2C customers (eg retail, food production). Of course there are some deviations from the general condition, as the IT industry, but in this case high activity in the field of public relations network should be seen in the profile of these companies.

The last part of the research, based on the opinions of experts in the field of public relations on a daily basis, showed that they generally agree on the anticipated trends in the analyzed material. The most important of the likely changes in the next few years passed, 
among others, the multidimensional development of social media and mobile applications. In the case of the former, in terms, include the growing importance of data obtained from this source, which is expected to lead to the building of more personalized messages. Content marketing will become even more important on this canvas. Companies will seek to be involved in an increase of all channels of communication with customers, which include even videos and various graphics (based on the social media boom in images). In turn, the case of mobile applications must be developed in a variety of niche solutions (often abbreviated - cycle of life) and light versions of all major social networks - in this case mobile versions - can definitely become more popular.

\section{REFERENCES}

[1] Bonek T., Smaga M., Biznes w Internecie. Praktyczny poradnik o marketingu, sprzedaży, public relations on-line i promocji w mediach spolecznościowych, Wolters Kluwer Polska, Warszawa 2012.

[2] Budzyński W., Public relations, strategia i nowe techniki kreowania wizerunku, Poltext, Warszawa 2008.

[3] Cyran M., Marketing 2.0. - zintegrowani z interaktywnymi, "Marketing w praktyce" 2008/10.

[4] Evans "Li" L., Social media marketing. Odkryj potencjat Facebooka, Twittera i innych portali społecznościowych, Helion, Gliwice 2011.

[5] Gajowniczek M., Internet liderem!, "Marketing w praktyce" 2009/8.

[6] Kotler Ph., Kartajaga H., Setiawan I., Marketing 3.0., MT Biznes, Warszawa 2010.

[7] Kowalska M., Zyskać przewagę. Zintegrowana komunikacja w nowoczesnym marketingu. Między teoria a praktyka, Wydawnictwo Adam Marszałek, Torun 2007.

[8] Mac A., E-przyjaciele. Zobacz, co media społecznościowe moga zrobić dla Twojej firmy, Helion, Gliwice 2011.

[9] Mazurek G., Promocja w Internecie. Narzędzia. Zarzadzanie. Praktyka, Ośrodek Doradztwa i Doskonalenia Kadr, Gdańsk 2008.

[10] Miotk A., Skuteczne social media, Helion, Gliwice 2013.

[11] Piekło B., Zweryfikowany serwis internetowy, "Marketing w praktyce" 2011/2.

[12] Podlaski A., Marketing społecznościowy. Tajniki skutecznej promocji w social media, Helion, Gliwice 2011.

[13] Scott D.M., Nowe zasady marketingu i PR, Oficyna Wolters Kluwer Polska, Warszawa 2009.

[14] Treadaway C., Smith M., Godzina dziennie z Facebook marketingiem, Helion, Gliwice 2013.

[15] Woźniakowski M., Pinterest jako przejaw kultury obrazkowej w komunikacji marketingowej przedsiębiorstw, [in:] Marketing w obliczu nowych wyzwań rynkowych, ed. W. Grzegorczyk, Wydawnictwo Uniwersytetu Łódzkiego, Łódź 2013.

[16] Woźniakowski M., Internetowe public relations $w$ komunikacji marketingowej przedsiębiorstw, unpublished doctoral dissertation, University of Lodz, Łódź 2014.

[17] Woźniakowski M., Internetowe narzędzia public relations w komunikacji marketingowej największych polskich przedsiębiorstw, "Przegląd organizacji” 2015/6.

\section{MEDIA INTERNETOWE W KOMUNIKACJI MARKETINGOWEJ POLSKICH PRZEDSIĘBIORSTW}

Głównym celem artykułu jest przedstawienie możliwości i zakresu wykorzystania nowych mediów dla potrzeb komunikacji marketingowej. Podstawę teoretyczną stanowią studia literaturowe opisywanego zagadnienia. W części empirycznej, która jest zasadniczą częścią opracowania, przedstawiono wyniki badań własnych autora na temat mediów internetowych w komunikacji marketingowej polskich przedsiębiorstw. Badania przeprowadzono 
w dwóch obszarach. Pierwszy odnosi się do analizy kontentu stron internetowych pod kątem wykorzystania narzędzi sieciowego public relations. Na tej podstawie dokonano diagnozy stanu obecnego wykorzystania nowych mediów w programach public relations przez badane przedsiębiorstwa. W drugim obszarze badawczym dokonano prognoz, odnoszących się do trendów rozwojowych mediów elektronicznych na przestrzeni kilku najbliższych lat na podstawie przeprowadzonych wywiadów eksperckich wśród przedstawicieli biznesu i nauki, zajmujących się tą tematyką. Ta część badawcza wykazała, że eksperci są na ogół zgodni co do przewidywanych trendów analizowanej materii. Do najważniejszych prawdopodobnych zmian w ciągu najbliższych kilku lat zaliczyli m.in. wielowymiarowy rozwój mediów społecznościowych oraz aplikacji mobilnych. W wypadku tych pierwszych chodzi m.in. o wzrost znaczenia danych pozyskiwanych z tego źródła, co ma doprowadzić do budowania bardziej spersonalizowanych przekazów. Na tej podstawie będzie zyskiwał na znaczeniu kontent marketing. Firmy będą dążyły do wzrostu zaangażowania we wszystkich kanałach komunikacji z odbiorcami, czemu służyć mają media społecznościowe bazujące na przekazie graficznym. $Z$ kolei jeśli chodzi o aplikacje mobilne, powinny się rozwijać różne niszowe rozwiązania oraz wersje mobilne wszystkich portali społecznościowych - w tym wypadku wersje mobilne powinny stać się zdecydowanie popularniejsze od pełnych.

Słowa kluczowe: komunikacja marketingowa, media internetowe, social media, media społecznościowe, public relations

\section{DOI: 10.7862/rz.2016.mmr.10}

Tekst złożono w redakcji: czerwiec 2016

Przyjęto do druku: czerwiec 2016 